\title{
Mathematical Interpretation of Global Competition between Payment Systems
}

\author{
Xinyu Cai ${ }^{1}$, Marko Milojevic ${ }^{2}$, Denis Syromyatnikov ${ }^{3}$, Anastasia Kurilova ${ }^{4}$ and Beata Ślusarczyk ${ }^{5,6, *}$ \\ 1 School of Labor Economics, Capital University of Economics and Business, Beijing 100070, China; \\ caixinyu@cueb.edu.cn \\ 2 Department of Accounting and Audit, Singidunum University, 11000 Belgrade, Serbia; \\ mmilojevic@singidunum.ac.rs \\ 3 Department of Economy and Foreign Economic Activity, North-Caucasus Federal University, \\ 355035 Stavropol, Russia; s-kulon09@yandex.ru \\ 4 Department of Masters Degree Programs (Business Programs), Togliatti State University, \\ 445051 Togliatty, Russia; aakurilova@yandex.ru \\ 5 The Management Faculty, Czestochowa University of Technology, 42-201 Czestochowa, Poland \\ 6 TRADE Research Entity, North-West University, Private Bag X1290, Potchefstroom 2520, South Africa \\ * Correspondence: beata.slusarczyk@pcz.pl
}

check for

updates

Citation: Cai, X.; Milojevic, M.; Syromyatnikov, D.; Kurilova, A.; Ślusarczyk, B. Mathematical

Interpretation of Global Competition between Payment Systems. Mathematics 2021, 9, 2070. https:/ / doi.org/10.3390/math9172070

Academic Editors: Octavian

Dospinescu and Juan

Jose García-Machado

Received: 22 July 2021

Accepted: 24 August 2021

Published: 27 August 2021

Publisher's Note: MDPI stays neutral with regard to jurisdictional claims in published maps and institutional affiliations.

Copyright: (c) 2021 by the authors. Licensee MDPI, Basel, Switzerland. This article is an open access article distributed under the terms and conditions of the Creative Commons Attribution (CC BY) license (https:// creativecommons.org/licenses/by/ $4.0 /)$.

\begin{abstract}
The present study seeks to present a mathematical interpretation of the perception of new entrants to the global payments market on whether FinTech's innovations promote competitiveness in the market. The study also quantitatively evaluates the competitive trends observed in the global payments market. The sampling frame consists of 504 respondents across 28 countries. The study is based on the analysis of the survey results using SPSS Statistics and Stata. The survey addressed four groups of factors influencing the competitiveness of the payment system (i.e., 'Costs', 'Service Channels', 'Privacy and Security', 'Quality and Efficiency'). The respondents believe that FinTech innovations have a strong positive effect on the payment system's competitiveness $(\mathrm{M}=4.32)$. The results of the present study may be of interest to specialists and researchers who deal with the competitive dynamics of the global payments business, with payment innovations, and with convergence and transformation of the payments industry.
\end{abstract}

Keywords: competitive dynamics; competitiveness; financial technology (FinTech); payment innovation; payment system

\section{Introduction}

The payments industry has historically been characterized by the presence of network effects, high fixed costs, and economies of scale [1]. Payment systems and remittances are considered the backbone of the financial sector, fostering economic growth and financial development by reducing systemic and settlement risks, facilitating proper liquidity management, and creating effective monetary policy [2]. Payment systems are of central importance for supporting financial inclusion; a transaction account allows people to make and receive payments in a cost-effective way [3]. Today, the global payments landscape is experiencing fundamental change [4], driven by the emergence of new technology and business methods, the rise of new economic powers, and changes in the global currency landscape [5]. A payment nowadays is viewed as something more than just the settlement of a transaction or the movement of funds. The broader commercial, retail, investment and public sector environments are taken into account, and the payment-related activities (such as investment decisions, trade-related financing and risk mitigation, the cross-border movement of wages and pensions, and more) make up the basis on which payment system providers develop better propositions [6-8]. Innovative payment methods introduced by non-banking players are increasingly changing the reality of traditional payment systems [9]. Even though the global payments business is already vast, it is expected to 
continue to expand under the influence of a number of factors and trends, some of which are having an impact at this very moment [6]. Global demographics are affecting the payments landscape by redistributing financial resources across borders. Fast-growing markets in Asia, Africa, and elsewhere are developing their own payment propositions and systems, including for e-commerce [10], especially since inflation in these regions significantly contributes to financial development in the short and long term [11]. In this respect, international remittances, especially to developing countries, represent another developing source of global payment flows requiring the development of systems to serve them [12].

The transformation of the global payment system takes place in a segmented manner [13]. Revision of the competitive environment, arrival of non-traditional suppliers on the market, development of new solutions and strategic alliances, and increasingly observed convergence all applies to products and solutions related to payments and technology platforms and clearing opportunities that are becoming more global [14]. With the emergence of a young tech-savvy generation, the expectations of retail and commercial customers for payments are becoming more and more consistent. They put forward more demands for convenience, security and flexibility of payments with the use of the most recent technologies [4]. What is more, today, consumer preferences are changing due to the convenience of contactless cards and mobile payments [15,16].

Notwithstanding the above, commercial banks can be key traditional market players. The central factors influencing competitive advantages of traditional payment service providers embrace competitive product prices, easy access to services, range of services offered, quality of service and management, and e-marketing innovativeness [17]. Indeed, the banking sector can now remain competitive in the payment system market if it responds quickly enough and takes advantage of the opportunities on offer in the global payments business [18]. Thus, the development of information and communication technologies is central to payment innovation in the 21st century.

The fact that competition is a complex concept and therefore cannot be directly observed has led to the development of many approaches to its assessment [19]. To a large extent, assessment of the competition in the banking industry has a long tradition. Early research in this field focused on the relationship between market structure and performance, or the structure-conduct-performance paradigm [20,21]. However, some authors raised serious doubts about its reliability, which stimulated the development of non-structural measures of competition, like the Lerner index, the conjectural variation model, the PanzarRosse model and the Boone indicator $[22,23]$. To assess the factors of competition and stability in the financial services market, many of them propose applying the Fuzzy Delphi Method (FDM) and the Interpretive Structural Modeling (ISM) approach [24]. On the other hand, while some researchers may prefer one model over the other, there is still no consensus on the best measure to assess competition. Different indicators of competition do not provide the same conclusions. A significant drawback of most approaches is their complexity and the need to collect a large amount of data. For this particular reason, such assessment can only be carried out by narrow specialists.

Thus, the main gap in the existing literature is considered to be the lack of simple approaches in determining the factors affecting the global competition of payment systems to study it as a qualitative phenomenon. The article formulates the following research questions (RQ): RQ1: “What are the current trends of competition in the global market of payment systems?"; RQ2: "What are the promising trends and the role of financial technology (FinTech) in the global competition of payment systems?"; RQ3: "What groups of factors influence the competitiveness of the payment system today?" RQ4: "How are the factors of global competition of payment systems interpreted by active payment market participants?".

The central aim of this study was to test a simple and interesting economic-mathematical approach to interpret the relevant factors affecting the global competition of payment systems. This was expected to enable the examination of the qualitative phenomenon of 
competition in the global payment system market through quantitative interdisciplinary approaches. As additional research goals, the authors focused on identifying and analyzing the current global payment system market's competitive trends and investigated the perception of the introduction of FinTech innovations by new market players as a decisive factor in payment systems' competitiveness.

\section{Literature Review}

2.1. Development Trends and Competition Conditions and Dynamics in the Global Payments Market

Alternative payment systems are beginning to play an increasingly important role in the payments space [25]. Hence, in Africa, for example, the number of those using the M-Pesa mobile payment system outnumber bank account holders, whereas in China, the market is conquered by the largest alternative payment method Alipay with more than 300 million users [10]. The geographic segmentation of the global payments market based on non-card transactions is shown in Figure 1.

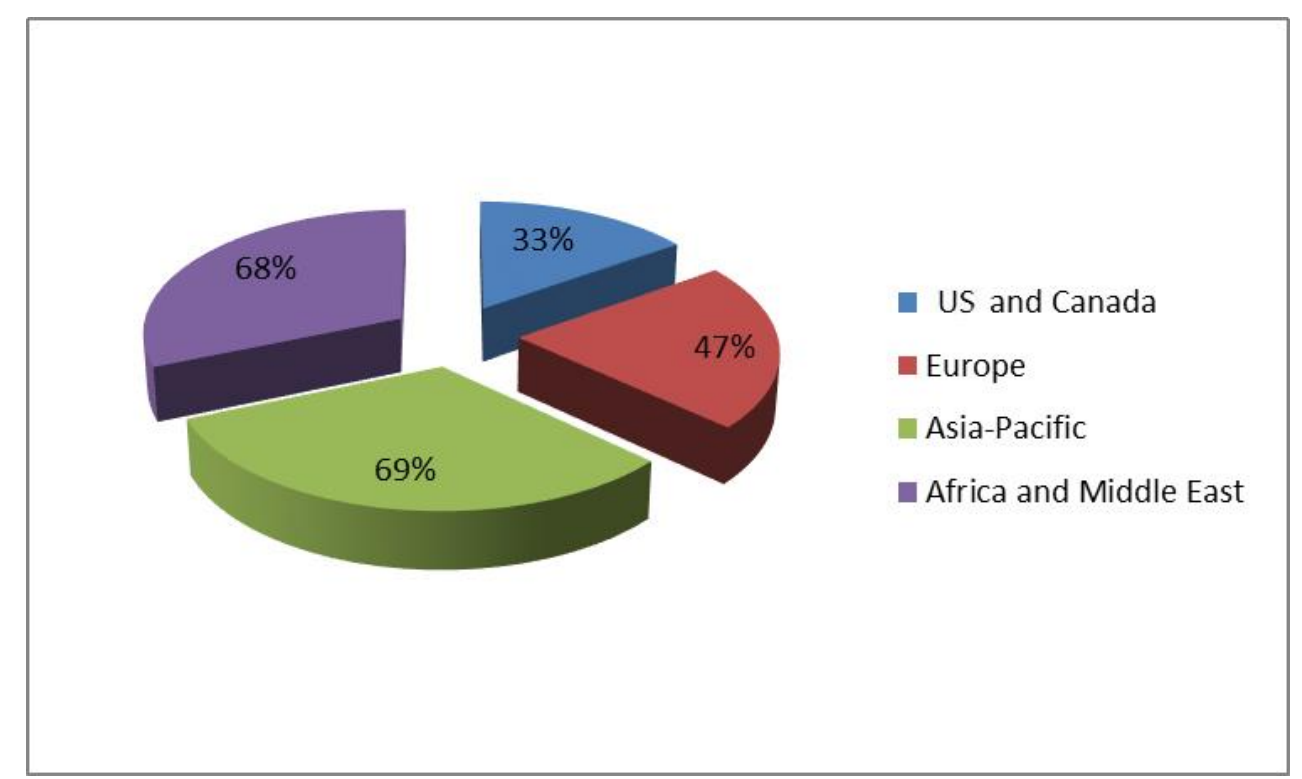

Figure 1. The 2019 percentage of non-card transaction volumes by region, developed by the authors based on data from WorldPay [26].

Relatively new entrants to the market are digital wallet providers taking advantage of increasingly popular method of payment. The penetration degree of digital wallets is depicted in Figure 2.

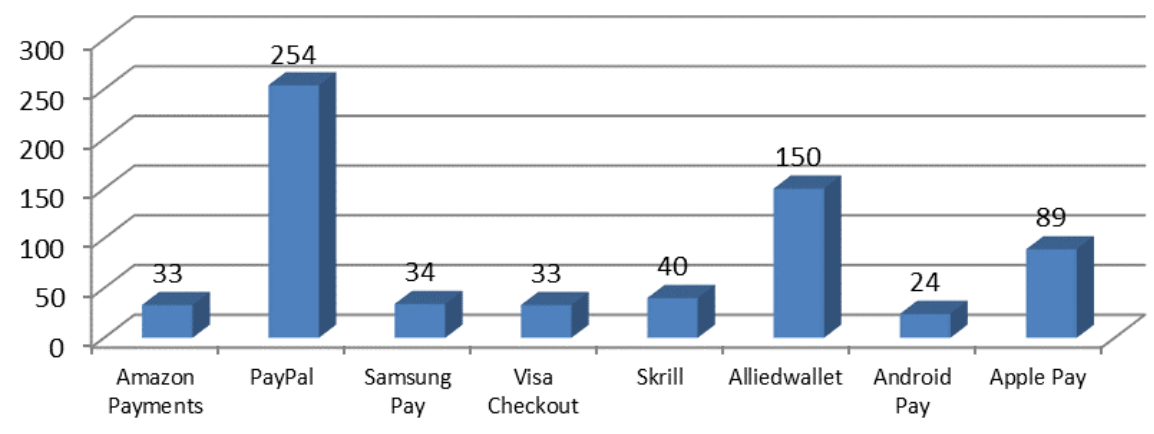

Figure 2. The 2018 number of digital wallet users (million users), developed by the authors based on data from Oxera [25]. 
In a number of European countries, digital wallets, as an alternative to traditional payment systems, account for a substantial share of online payments: $30 \%$ in Italy, $25 \%$ in Denmark, Germany, Spain, the UK, and 20\% in France [27]. And their popularity is likely to keep growing. Rather than using a traditional Visa or Mastercard, people worldwide increasingly prefer to use mobile systems providing convenient access to a variety of payment methods [16]. According to Accenture's report, the global mobile payments market has been growing $24 \%$ per year since 2015 (Figure 3).

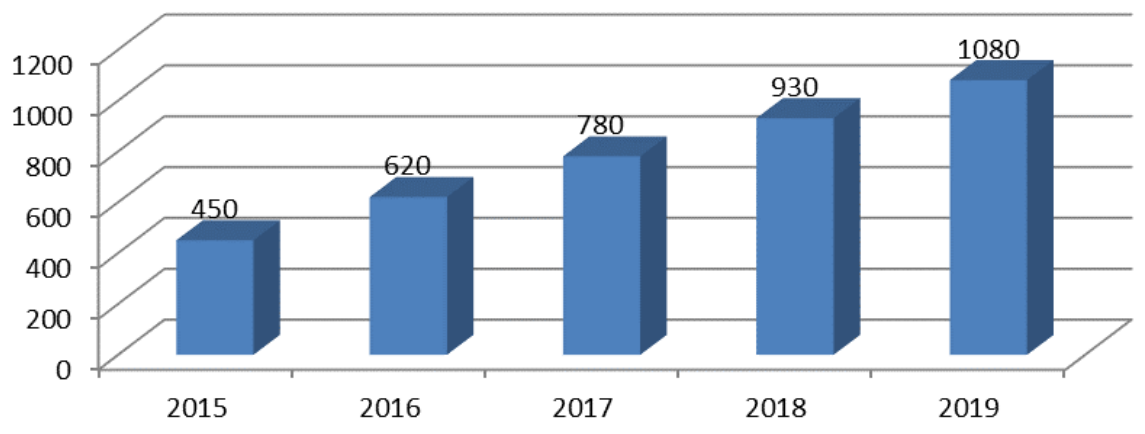

Figure 3. The state of the global mobile payments market between 2015 and 2019 (billion US dollars), developed by the authors based on data from Accenture [28].

In view of this, it is quite natural that such positive dynamics of the global payments market trigger the emergence of new payment systems and the increasingly pronounced activity of factors forming the competitive panorama of the global payments market (Tables 1 and 2).

Table 1. Major trends of demand in the global payments market.

\begin{tabular}{ll}
\hline \multicolumn{1}{c}{ Trend } & Context \\
\hline $\begin{array}{l}\text { Transformation \& Convergence } \\
\begin{array}{l}\text { Transformative power of } \\
\text { technology }\end{array}\end{array}$ & $\begin{array}{l}\text { The nature of competition between payment systems implies changes with the entry of new competitors. The role of social } \\
\text { media, online payment providers, and virtual marketplaces will continue to expand. The product- and solution-level } \\
\text { integration is expected, so does the cross-border alignment of payment infrastructures. }\end{array}$ \\
\hline $\begin{array}{l}\text { Regulation \& global political } \\
\text { factors }\end{array}$ & $\begin{array}{l}\text { Increasing regulatory pressure on banks may emerge, which will reduce their ability to develop attractive payment offerings. } \\
\text { Competitive opportunities are emerging for non-bank players to develop offerings for different customer segments. The } \\
\text { multipolar nature of political power will affect the demand for and provision of cross-border payments. }\end{array}$ \\
\hline $\begin{array}{l}\text { Technological breakthroughs in } \\
\text { emerging markets }\end{array}$ & $\begin{array}{l}\text { Due to the absence of traditional payment infrastructure and technology hindering progress, advanced technical platforms are } \\
\text { actively emerging in emerging markets, bridging the available gap and posing a competitive threat to traditional banking. }\end{array}$ \\
\hline
\end{tabular}

Source: Bott and Milkau [4], Berg et al. [5], Jeziorski [29], The Bank of New York Mellon Corporation [30], WorldPay [26].

Table 2. Major trends of supply in the global payments market.

\begin{tabular}{|c|c|}
\hline Trend & Context \\
\hline $\begin{array}{l}\text { Changes in trade and capital } \\
\text { flows }\end{array}$ & $\begin{array}{l}\text { The payments landscape is evolving against the background of accelerating global redistribution of wealth, liquid assets and } \\
\text { payment-related resources towards emerging markets, affecting the nature of the global payments business. }\end{array}$ \\
\hline Changing demographics & $\begin{array}{l}\text { The accelerating growth of young and educated middle class in emerging markets such as China and Indonesia is fueling these } \\
\text { countries' payment flows. Shifts in demographics coupled with changes in capital and trade flows will drive the payment } \\
\text { infrastructure evolution. }\end{array}$ \\
\hline $\begin{array}{l}\text { Small and medium-sized } \\
\text { enterprises }\end{array}$ & $\begin{array}{l}\text { Small and medium-sized businesses underserved by traditional providers of finance and payments will target alternative } \\
\text { providers that offer solutions through cost-effective technology platforms. }\end{array}$ \\
\hline Consumers shaping change & $\begin{array}{l}\text { Consumer experience and expectations will account for perhaps } 70 \% \text { of what shapes the evolution of payments, while the needs } \\
\text { and expectations of commercial customers will determine the remaining } 30 \% \text {. The decisive role will belong to smartphone and } \\
\text { tablet technologies capable of enabling complex transactions in a relatively secure environment. }\end{array}$ \\
\hline
\end{tabular}

Source: Bott and Milkau [4], Berg et al. [5], Jeziorski [29], The Bank of New York Mellon Corporation [30], WorldPay [26].

Those trends above imply that competitive dynamics in the payments market will intensify, providing opportunities for new entrants to come into the market [31]. To overcome barriers to entry and expand in the market, new entrants tend to pursue strategies that 
allow building up the critical mass required to gain a substantial share of the market [25]. The main types of competition between payment systems are depicted in Figure 4.

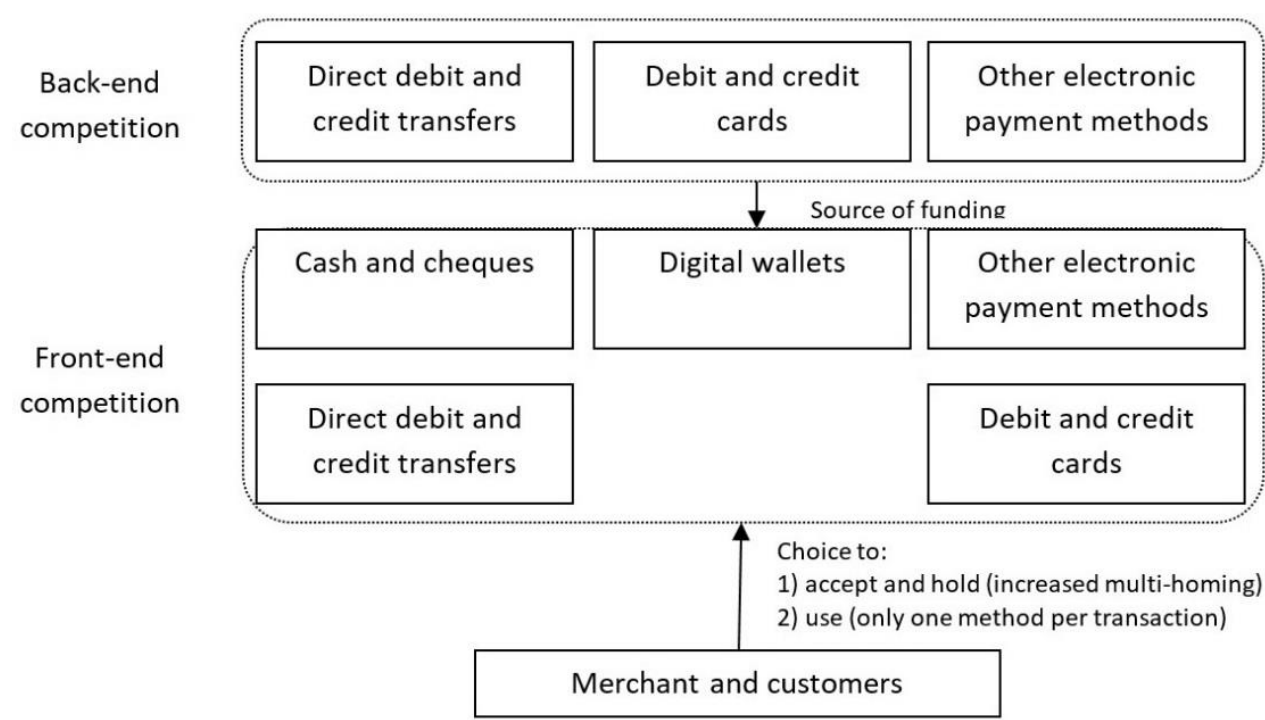

Figure 4. Types of competition between global payment systems, developed by the authors based on data from Oxera [27].

\subsection{Back-End Competition in Global Payment Systems}

Providers competing for potential customers can use a variety of solutions to strengthen their competitive position in the market. Generalization of these solutions allowed us to conclude that back-end competition is characterized by the following:

- Leveraging an existing customer base from other markets. Innovative providers tightly connected to payments as a part of their activity use the accumulated customer bases to implement the payment system function [29,32]. For example, retailers such as Amazon and Carrefour took advantage of their customer base to introduce digital wallet services for online payments, and mobile phone manufacturers such as Apple and Samsung have used their large user bases and near-field communication technology to enable payment services [27]. They consider factors such as the quality of the system, information and services to encourage consumers' intentions to use mobile payments [33]. Big tech and social media companies like Amazon, Google and Facebook are also seeking to enter the payments market. If social media companies can monetize significant customer reach by providing simple and secure payment options, they may succeed in removing bank intermediation [34].

- Taking advantage of competitive advantages resulting from demographic trends and physical movement of payment system users [35]. China UnionPay, for example, entered the European market thanks to the growing number of Chinese tourists [36].

- Creation of a new customer base by companies able to create market niches on their own [37,38]. This tactic has been used by a number of companies such as PayPal, Klarna, Sofort, and Trustly that have successfully entered the market and even expanded it by offering a more convenient service for consumers and retailers [39].

- Adaptation and use of the existing payment infrastructure for processing transactions [40]. For example, a PayPal wallet is linked to credit and debit cards, as well as to a current bank account, which facilitates the company's entry to the payment market [2]. Electronic transaction providers also strengthen their security practices by ensuring accessibility, authorization, authentication, and confidentiality [41], competing with banking services at the level of the global system [42].

- Formation of opportunities for new players in the market and harder competition for traditional banking institutions due to the introduction of the Payment Services 
Directive 2 (PSD2) [43]. This directive is planned to be ratified in several EU countries (e.g., Ukraine), which will subsequently result in an extensive market. The PSD2 technology makes it easier for new competitors to enter the market by leveraging the existing interbank processing infrastructure [35]. In sum, PSD2 is expected to change the financial services landscape, forcing traditional financial service providers and banks to come up with new business models to remain competitive [12]. FinTech companies are ranked first among the payment system players benefiting from the implementation of PSD2. This can become a new era for FinTechs insofar as it is expected to improve the user experience and launch new innovative products [44]. Companies will be able to build their applications using payment initiation capabilities and customer account information that was previously only available to banks.

\subsection{Front-End Competition in Global Payment Systems}

Front-end competition refers to competition between payment methods held and used on the consumer side, and accepted on the merchant side. Consumers and merchants have an increasingly wide range of payment methods for in-store and online transactions, which enhances competition at the following two levels [4]:

- Competition for a customer base, whereby payment service providers compete to make merchants accept their payment method and customers utilize it.

- Competition for the use of payment method online and in stores, whereby payment service providers try to influence consumer decisions about which payment method to use.

No less important here is the increasing role of new players on the market, whose flexibility and ability to adapt pushes back the sluggish large banking representatives. The most striking trends shaping the front-end competition in global payment systems are:

- Intensified competition through multi-homing, which is becoming increasingly simple [6]. The number of consumers and merchants in the market continues to grow and customers increasingly have access to multiple payment methods. Therefore, multi-homing takes on a number of forms, from ownership of multiple cards to the growth of digital wallets [45]. Simple electronic payment methods that do not require significant effort to use become more available to users. For example, Apple Pay and Samsung Pay are available to consumers with Apple and Samsung devices [28]. However, these trends are putting additional pressure on conventional payment infrastructure and its ability to offer personalized payments [37].

- Ability to influence consumer choices of a payment method by setting minimum payments for certain payment types or a certain payment method as the default [31] For example, in France, the preferred payment brand is Cartes Bancaires, which is selected automatically unless rejected by the consumer [12].

- Payment methods' competition for use [46]. Payment providers compete by making the use of their payment products as convenient as possible and by offering additional services to users. For example, digital wallets such as PayPal and Amazon Pay automatically enter the consumer's address on the merchant's website. PayPal offers consumer protection against fraud or non-delivery, and Klarna offers Pay Later in 30 days [26]. The COVID-19 pandemic led to considerable changes in retail payments, providing a competitive edge for non-traditional forms of payment [47]. Consumers around the world have increased their use of contactless cards due to concerns about the transmission of viruses through cash, temporary closure of physical stores, and the rise of e-commerce. Thus, the COVID-19 pandemic has caused a surge in the use of online payments [48].

- Changing competitive dynamics for payments by adding new competitive conditions. In this context, the matter first of all stands for the consumers' ability to easily switch between payment methods without changing the front-end service they use [49]. New entrants to the global payments market such as Amazon, Apple, and Samsung have significant trading power [12]. For example, Apple is gradually increasing the 
number of banks that support Apple Pay for cards [50]. If banks refuse to accept this concession, they will risk losing a large number of transactions and customers [9]. Digital wallets have the capability to reduce reliance on major payment methods. As their user base grows, they will be able to internationalize most of their transactions, removing dependence on competing payment methods and reducing the total volume of transactions made via these methods. With the PSD2 technology, digital wallets can apply for PISP licenses, enabling secure transactions without requiring users to deposit money into the wallet in advance. This will further increase competitive pressure on traditional card systems [27].

- Taking advantage of technology to vertically integrate (or develop own payment processing infrastructure). For example, the social network Facebook has been granted an e-money and payment institution license in Ireland [51]. Amazon holds a payment institution license in the UK and Google in the UK, Lithuania, and Ireland [52]. On the other hand, traditional payment service providers are looking for new ways to collaborate. For example, Mastercard has entered into agreements with PayPal and expanded its digital partnership to Europe [53]. Banks are launching their own digital wallets such as Masterpass and Visa Checkout [54]. Attention is focused on geographic diversification and integrated solutions. For example, M-Pesa, launched in Kenya, now operates in Eastern Europe. Kipochi, an e-wallet service, has also linked M-Pesa with bitcoin, enabling the exchange of value where M-Pesa is not available [39].

\subsection{Promising Trends and the Role of FinTech in Competition for Payments}

Competition is one of the drivers influencing the payments industry. Indeed, it is difficult to foresee the likely development of the payments market due to the many factors shaping it, such as technology, new types of business, etc. [39]. Particular emphasis is placed on research that focuses on environmental, social, and corporate criteria that comprehensively shape the sustainability of the payment system [55]. Nevertheless, some aspects of this process can be predicted with reasonable certainty. Scholars suggest that the major trends the payments industry is likely to face in the coming years are: (1) the growing role of providers not specializing in payments; (2) more opportunities to steer the choice of payment methods; (3) the blurring of boundaries between online and physical payments (such as paying for an Uber driver through an app); (4) increasing competitive pressure from provides using PSD2; (5) the rise of alternative payment infrastructures [31,56]. As a result of these trends, competitive pressure will increase in the payments market. Providers unable to reach competitive scale in terms of user base can expand their influence through consolidation.

As already emphasized above, FinTech companies are among the central drivers of the current (and future) payment market, and influence both its dynamics and the competitive situation [43]. Financial technology is seen as a new market that integrates financial services and technology. Currently, FinTech includes numerous technology startups and large organizations trying to improve and optimize financial services provided. They use technology and innovation to compete with traditional financial institutions represented by banks and intermediaries in the financial service and payment market [57]. The introduction of new technologies to the financial sector brings many benefits to both providers and users of payment services. They improve business efficiency, reduce the cost of financial products and services through higher standardization, improve the quality and ensure better individualization of products [35]. The popularity of FinTech innovations grew with the emergence of FinTech startups in recent years that aggressively build their client base [58]. The payments industry, now dominated by a relatively small number of giant companies (in particular, in the B2C space), is one of the most dynamic segments out there, but the leading companies in point make poor use of technological innovations and thus are easily amenable to competitive attacks by FinTech startups [59].

Advances in FinTech have the potential to affect the competitiveness of traditional payment service providers by enabling them to replace traditional financial structures 
with new technology-based processes [60]. FinTech innovations can involve new products, service channels, security and privacy issues, and more. One of the crucial factors that allow FinTech companies to enter the payments market is substantially lower regulation of financial services provided by non-banks. Research based on a sample of today's active payment system users (Millennials and Generation Z) states that the most important factors determining their level of satisfaction with FinTech services include convenience and simplicity, as well as numerous mobile payment features (international transfers, crowdfunding, online brokerage, cryptocurrency transactions) [61,62]. Among the underlying factors for the adoption of new technologies is also the criterion of user confidence in FinTech [63]. It is argued that increased competition from the non-bank payment service providers should be encouraged to remove dominance of the traditional banking sector [64]. In addition, it is not infrequent that FinTech companies are much better and faster to consider the dominant factors determining the ability of the payment system to compete in the global market [43]. As a rule, such factors encompass the ability to minimize the cost of developing solutions and ensuring their availability, the ability to offer innovation in terms of communication, marketing, service offering and distribution $[13,49,65,66]$, the ability to generate technologies to continuously improve customer satisfaction through the service quality and payment efficiency $[13,46,66]$, and provision of customer base security and privacy $[46,67,68]$.

The main advantage of new entrants is that they focus on improving customer relationships at the POS (Points of Service) and are more effective in utilizing new technology. At the same time, PayPal remains the undisputed leader in the digital payments segment in the United States and Europe, while Apple Pay and Android Pay rank first in mobile payments worldwide. In China, the top players are Alipay and WeChat. Companies such as TransferWise, Remitly, WorldRemit and Azimo revolutionize the remittance segment. Xoom makes more money online than MoneyGram, the second largest traditional remittance company with 75 years of market history [59]. Thus, technological advances and increased competition in the payments market encourage the banking sector to shift its strategy towards improving customer satisfaction and service quality, introducing new services, and building partnerships with technology-oriented companies.

In such a manner, this study raises the question regarding the market outlook for payment systems, or more precisely, how the impact of FinTech innovations (as specific factors) on the global competitiveness of payment systems will be assessed.

\section{Materials and Methods}

\subsection{Methods and Instruments}

The present study is based on the analysis of data collected through a survey of FinTech companies offering payment services to customers of traditional payment institutions.

Descriptive statistics for numeric variables obtained in SPSS Statistics was used in evaluating the potential of using FinTech solutions to improve the competitiveness of payment systems. The association between variables was assessed using the Stata software package.

Since the study benefited from an ordinal measurement scale, the median value (MD) was used as a measure of central tendency and the interquartile range (IQR) as a measure of statistical dispersion. In cases when elements could be grouped, the reliability of internal consistency was measured using Cronbach's alpha $(\alpha)(0.82)$. The Friedman test, a nonparametric test for comparing more than two related samples, was applied to rank-order the measures. Differences between the studied groups were determined via posteriori comparison. The comparison of the absolute values of the severity of shifts in one direction or another was carried out using the Wilcoxon test, used to compare the absolute values of differences. The issue of multiple comparisons arising in the posteriori test was eliminated through Bonferroni correction, the simplest and the most popular approach for correcting type 1 errors. The Wald test was employed to assess constraints on statistical 
parameters. The Pearson's $r$ correlation was used to determine whether there was a linear relationship between the two variables.

\subsection{Study Population}

The sample of FinTech representatives was generated in 2019 using LinkedIn. The choice of this platform can be explained by its focus on finding and establishing business contacts. LinkedIn is a network of more than 500 million professionals representing 150 industries from 200 countries around the world, which actually meets the requirements for the respondents to be engaged in business, as well as for their geographical diversification. The choice of LinkedIn was also dictated by the fact that it has many representatives of emerging companies that are active in their segment and tend to respond quickly to the changing competitive environment.

When selecting the study respondents, the key factor was having at least three years of experience in FinTech (both in startups and mature companies like Cake, Sthaler, WorldRemit, or Klarna) and experience in developing payment systems for large non-traditional players, e.g., Amazon, Apple, or Samsung. In total, an e-mail invitation asking to participate in an online survey and providing a link to the questionnaire was sent to 320 candidates. Of them, 271 responded positively, and 258 completed the questionnaire they had been sent. The distribution of respondents by region is depicted in Figure 5.

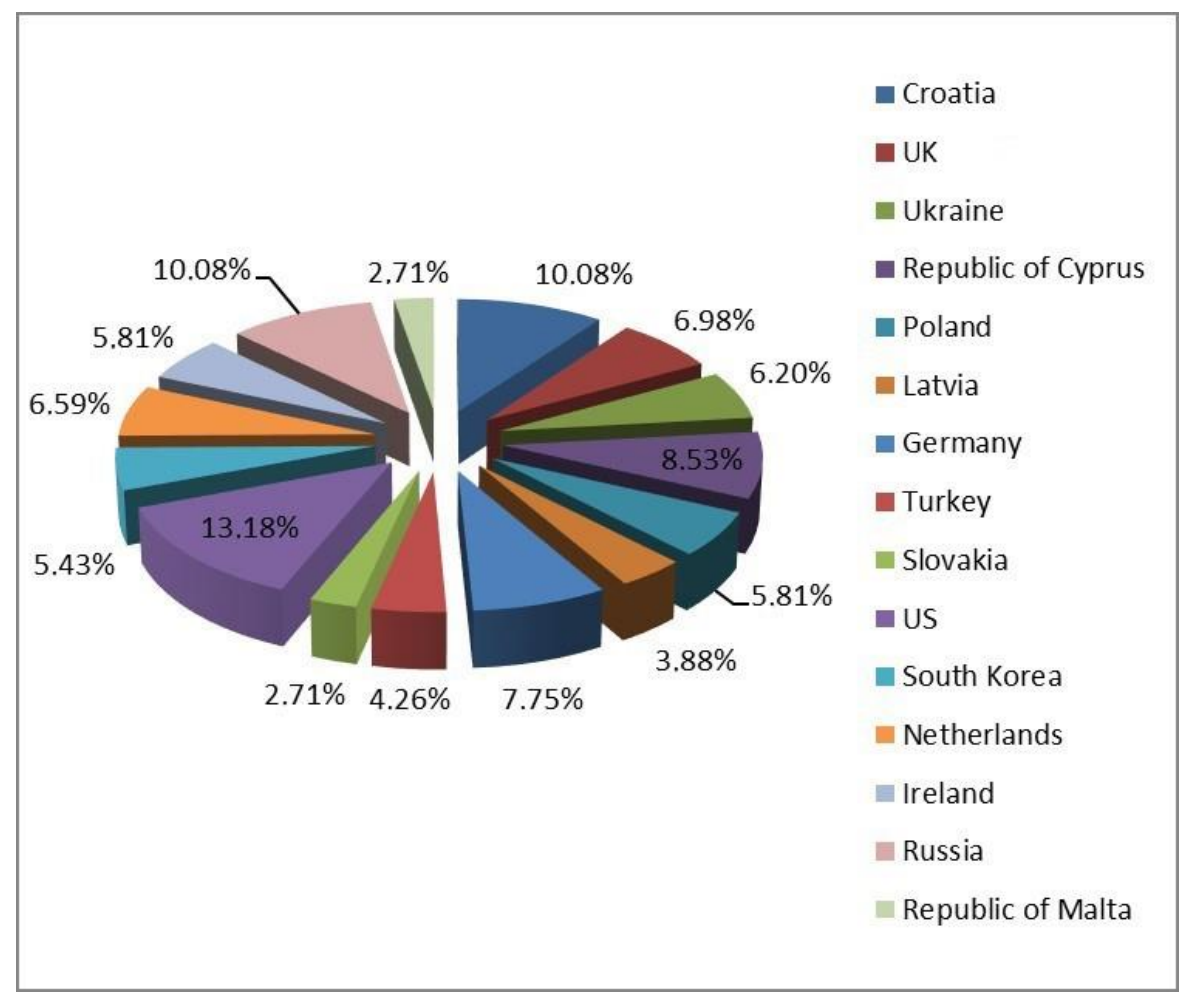

Figure 5. Respondent distribution (\%), developed by the authors.

The need to balance the composition of the respondents led to the organization of an additional survey. With the help of the LinkedIn social network, representatives of FinTech companies from the Asia-Pacific region, as well as from the Gulf countries and African states, were found and invited to become the study respondents. Thus, invitations to be enrolled in the survey (it was held in an online mode) were sent to 287 individuals. Positive responses were collected from 262 potential respondents, though completed questionnaires were received from only 246 of them $(n=246)$. The results of additional sampling are presented in Figure 6. 


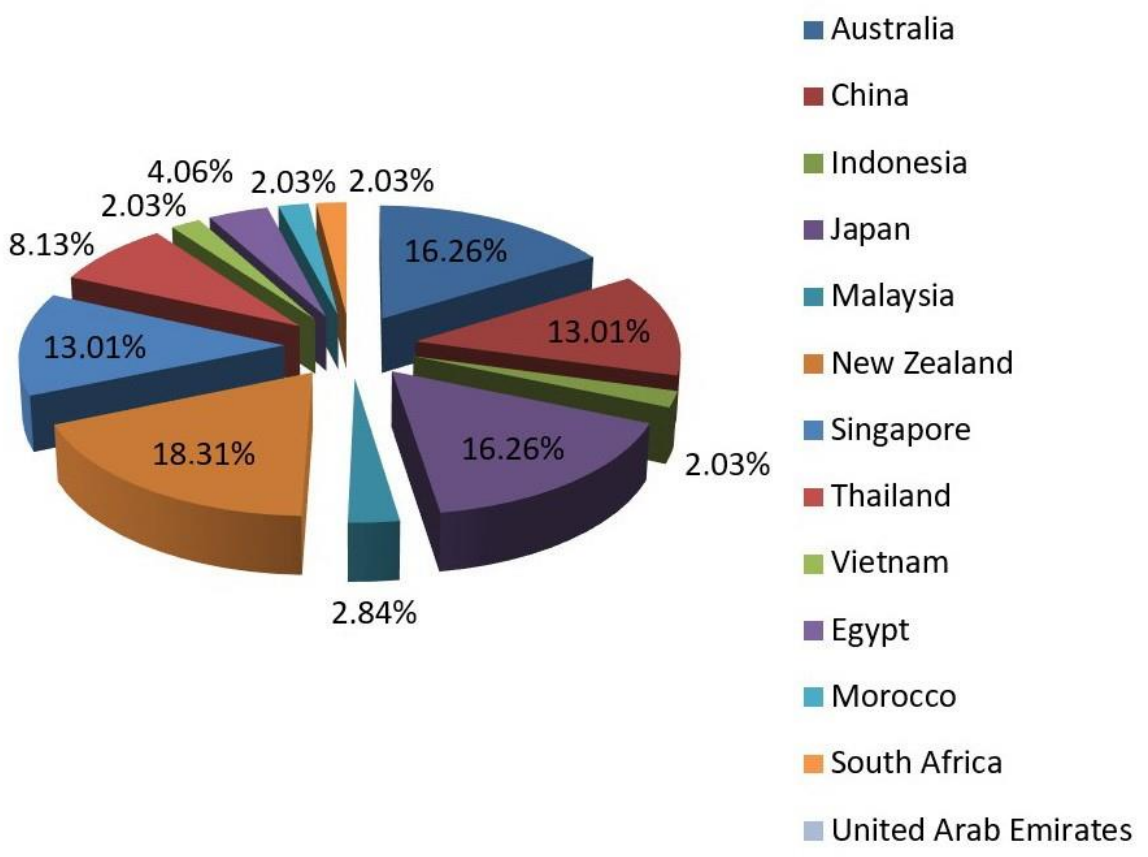

Figure 6. Geographic distribution of the additional sample of respondents (\%), developed by the authors.

Hence, the final sample consisted of 504 individuals from 28 countries.

\subsection{Study Design}

Summarizing the existing theoretical framework allowed us to identify four main categories of factors, which, within the current research, were defined as exerting the most substantial influence on the competitiveness of the payment system [13,49,65-68]:

- Costs, involved in implementing and maintaining availability solutions.

- Service channels, which refers to innovations in products and services that allow for better communication, marketing and sales, as well as the development of new proportions, fueling the competition.

- Privacy and Security, implying that technology must ensure that client's personal information and data of transactions are stored securely, privacy is maintained, and risks are reduced.

- Quality and Efficiency, which refers to the use of technology as a means of improving the quality of service and efficiency of payments.

In the survey, respondents were asked to enter the country in which their company is located and rank their perceptions of whether FinTech innovations facilitate the gain of a competitive advantage. Respondents were asked to rank the impact of FinTech innovations on the competitiveness of the payment systems using a 5-point Likert scale [69], ranging from ' 1 ' (FinTech innovation is perceived to have a negative impact on the competitiveness), to ' 5 ' (FinTech innovation is perceived to have a positive impact on the competitiveness). The following items were designed to assess the importance of those factors above to competitiveness: 'Costs', 'Service channels', 'Privacy and Security', and 'Quality and Efficiency'. Each of these items was on a 5-point Likert scale, ranging from ' 1 ' (no importance) to ' 5 ' (high importance).

As regards the study design, all participants were told that participation in the survey was voluntary. The sample thus includes representatives of FinTech companies who expressed a desire to contribute to modernizing the methodological apparatus for identifying factors of the payment system global competitiveness. As a result, this study draws on data not subjected to the authors' interpretation and preliminary statistical processing by government services and commercial agencies. Hence, the involvement of FinTech representatives made it possible to improve the objectivity of the study. 


\subsection{Limitations}

Some decisions made regarding the research procedure make it impossible to use the goodness-of-fit test to evaluate whether distributions differ significantly from each other with respect to the geographic groups. In addition, the Bonferroni correction used to solve the issue of multiple comparisons could increase the risk of generating type 2 errors (false negatives).

Another source of possible uncertainty is the lack of the ability to form a research sample based on the share of FinTech companies' distribution across countries. The impossibility of such an approach to be realized in an adequate form is explained by a rather substantial part of the shadow economy in many states, which would actually have made the FinTech share present with large errors in advance. Another limitation is associated with the voluntary nature of the survey, which did not allow an extensive range of countries.

\subsection{Ethics}

The respondents were guaranteed non-disclosure of personal and professional data. When filling out the questionnaire, respondents were told that they would indicate only the country of the company's origin, and that no personal data or details about the company would be taken. Each questionnaire was assigned a number.

\section{Results}

\subsection{Attitude to FinTech Innovations as a Factor of Competitive Advantage}

General attitudes toward FinTech innovations were elucidated by processing the results of the survey conducted at the first stage of the sample formation. The survey results (Figure 7) show that FinTech representatives perceive FinTech innovations as having a strong impact on the competitiveness of the payment systems $(\mathrm{M}=4.32)$.
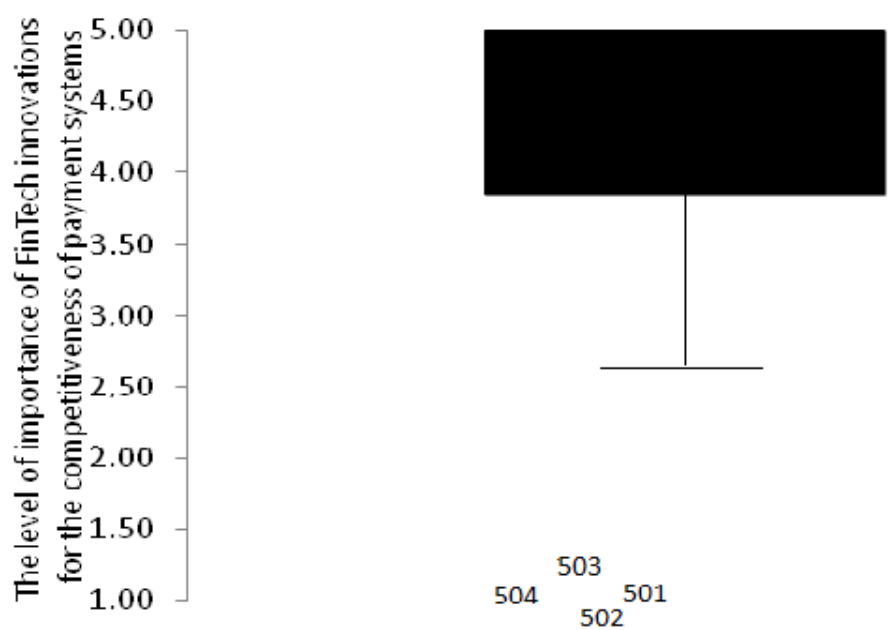

Figure 7. Perception of whether FinTech innovations boost competitiveness of the payment system, developed by the authors.

\subsection{Perceptions of the Importance of Costs}

The respondents indicated that they perceived Costs as playing a substantial role in the payment system's competitiveness (Table 3). The cost of technology implementation was identified as the most important factor, perhaps because it determines the price of the payment product or service. The cost of maintaining and servicing the technology was ranked as less important. The scales are ordinal and range from 'Low importance' (1) to 'High importance' (5). The letters A-C indicate statistically significant differences in the importance of factors at $p \leq 0.005$ (after applying the Bonferroni correction). The result of the Friedman test equals $\chi^{2}(2)=291.84, p \leq 0.001$. 
Table 3. Respondents' perceptions about the importance of Costs, developed by the authors.

\begin{tabular}{ccccc}
\hline & Median & IQR (Range) & Mean Rank & Wilcoxon Test \\
\hline The Costs of Technology & 5 & $5-5(3-5)$ & 2.35 & A \\
Implementation & 4 & $4-4(3-5)$ & 1.41 & B \\
Maintenance and Servicing Costs & 5 & $5-5(3-5)$ & 2.25 & $\mathrm{C}$ \\
The Costs to Customers & 5 &
\end{tabular}

\subsection{Perceptions of the Importance of Service Channels}

The respondents indicated that they perceived Service Channels as being important, ranking' availability of innovative products and services' and 'marketing and awareness of innovative products and services' as the most important factors (Table 4). This finding suggests a competitive payment system must offer both innovative products and services to create the need and inform about the existing proposals. The scales are ordinal and range from 'Low importance' (1) to 'High importance' (5). The letters A-B (none of the criteria fell into the $C$ category) indicate statistically significant differences in the importance of factors at $p \leq 0.005$ (after applying the Bonferroni correction). The result of the Friedman test is $\chi^{2}(2)=86.74, p \leq 0.001$.

Table 4. Respondents' perceptions about the importance of Service Channels, developed by the authors.

\begin{tabular}{ccccc}
\hline & Median & IQR (Range) & Mean Rank & Wilcoxon Test \\
\hline $\begin{array}{c}\text { Application of Modern Technology } \\
\text { Availability of Innovative Products } \\
\quad 5\end{array}$ & 5 & $5-5(4-5)$ & 1.82 & $\mathrm{~B}$ \\
$\begin{array}{c}\text { and Services } \\
\begin{array}{c}\text { Marketing and Awareness of } \\
\text { Innovative Products and Services }\end{array}\end{array}$ & 4 & $5-5(4-5)$ & 2.10 & $\mathrm{~A}$ \\
\hline
\end{tabular}

\subsection{Perceptions of the Importance of Privacy and Security}

The respondent's perception of 'security' is that it is of priority importance, followed by 'risk' and 'privacy' (Table 5). This leads to the conclusion that the payment system delivery should be carried out exactly as per request. This group of factors not only promotes competitiveness, but it also affects the operation of the payment service providers. The scales are ordinal and range from 'Low importance' (1) to 'High importance' (5). The letters A-C denote statistically significant differences in the importance of factors at $p \leq 0.005$ (after applying the Bonferroni correction). The result of the Friedman test amounts to $\chi^{2}(2)=30.26, p \leq 0.001$.

Table 5. Respondents' perceptions about the importance of Privacy and Security, developed by the authors.

\begin{tabular}{ccccc}
\hline & Median & IQR (Range) & Mean Rank & Wilcoxon Test \\
\hline Risk & 5 & $5-5(3-5)$ & 1.98 & $\mathrm{~B}$ \\
Security & 5 & $5-5(3-5)$ & 2.11 & $\mathrm{~A}$ \\
Privacy & 5 & $5-5(3-5)$ & 1.91 & $\mathrm{C}$ \\
\hline
\end{tabular}

\subsection{Perceptions of the Importance of Quality and Efficiency}

For respondents, the Quality and Efficiency played an essential role in the payment system's competitiveness (Table 6). 'Customer satisfaction' and 'the use of latest technology' have been identified as the most important factors. The latest technology is customerorientated and helps to ensure customer satisfaction. Hence, companies that utilize novel tech can gain more competitive advantages. The scales are ordinal and range from 'Low importance' (1) to 'High importance' (5). The letters A-B (none of the criteria fell into the C category) signify statistically significant differences in the importance of factors at $p \leq 0.005$ 
(after applying the Bonferroni correction). The result of the Friedman test is $\chi^{2}(2)=67.75$, $p \leq 0.001$.

Table 6. Respondents' perceptions about the importance of Quality and Efficiency, developed by the authors.

\begin{tabular}{ccccc}
\hline & Median & IQR (Range) & Mean Rank & Wilcoxon Test \\
\hline Use of Latest Technology & 5 & $4-5(3-5)$ & 4.48 & $\mathrm{~A}$ \\
Speed of Transaction & 4 & $4-4(3-5)$ & 4.18 & $\mathrm{~B}$ \\
Customer Satisfaction & 5 & $4-5(3-5)$ & 4.56 & $\mathrm{~A}$ \\
\hline
\end{tabular}

4.6. Relationship between Each Independent Factor (i.e., 'Costs', 'Service Channels', 'Privacy and Security', and 'Quality and Efficiency') and Dependent Variable (i.e., 'Attitude to FinTech Innovations as a Factor of Competitive Advantage')

The analysis of survey results was followed by an ordered logistic regression to assess the relationship between each independent factor and the dependent variable 'the attitude to FinTech innovations as a factor of competitive advantage'. For this step, it was decided to remove variables relating to perception on service channels due to the lack of variation in the respondents' answers. The results of calculation are depicted in Table 7.

Table 7. Results of ordered logistic regression, developed by the authors.

\begin{tabular}{cccc}
\hline & Coefficient & $\begin{array}{c}\text { Robust Standard } \\
\text { Error }\end{array}$ & z-Statistic \\
\hline The Costs of Technology Implementation & $2.6473^{\mathrm{a}}$ & 1.5324 & 1.74 \\
Maintenance and Servicing Costs & $3.5898^{\mathrm{b}}$ & 1.0786 & 3.30 \\
The Costs to Customers & -0.3472 & 1.4498 & -0.25 \\
Risk & 0.2123 & 0.6150 & 0.42 \\
Security & -0.3686 & 0.4922 & -0.68 \\
Privacy & 0.9360 & 0.8398 & 1.08 \\
Use of Latest Technology & 0.0981 & 0.4305 & 0.28 \\
Speed of Transaction & 0.5385 & 0.4432 & 1.22 \\
Customer Satisfaction & $1.1533^{\mathrm{b}}$ & 0.3694 & 3.15 \\
\hline
\end{tabular}

Note: ${ }^{\mathrm{a}}$ —-statistical significance at the $10 \%$ level; ${ }^{\mathrm{b}}$ — statistical significance at the $1 \%$ level.

The $\mathrm{z}$ scores in Table 7 above indicate the statistical significance of each coefficient. Factors such as 'implementation costs' $(z=1.74)$, 'maintenance and servicing costs' $(z=3.30)$, and 'customer satisfaction' $(z=3.15)$, provide statistically significant coefficients. The Pseudo R-Squared equals 0.4886; therefore, the factors jointly explain almost half of the variation in respondents' perceptions. The Wald statistic is significant at the $1 \%$ level, implying that the resulting regression coefficients are collectively different from 0 . The next step was the correlation analysis (Table 8). Its results indicate that the possibility for insignificant coefficients for the other variable could be the multicollinearity among them. 
Table 8. Correlation analysis of data from questionnaires.

\begin{tabular}{|c|c|c|c|c|c|c|c|c|c|}
\hline & & $\mathrm{CC}$ & MSC & $\mathbf{P}$ & $S$ & $\mathbf{R}$ & CS & ST & ULT $^{a}$ \\
\hline \multirow[t]{2}{*}{$\mathrm{CC}$} & $\begin{array}{l}\text { Pearson } \\
\text { Correlation }\end{array}$ & 1 & $0.918^{* *}$ & $0.959^{* *}$ & -0.024 & $0.936^{* *}$ & $0.547^{* *}$ & 0.392 ** & 0.661 ** \\
\hline & Sig. (2-tailed) & & 0.000 & 0.000 & 0.751 & 0.000 & 0.000 & 0.000 & 0.000 \\
\hline \multirow[t]{2}{*}{ MSC } & $\begin{array}{c}\text { Pearson } \\
\text { Correlation }\end{array}$ & 0.918 ** & 1 & $0.882^{* *}$ & -0.026 & $0.856^{* *}$ & $0.527^{* *}$ & $0.368^{* *}$ & $0.619 * *$ \\
\hline & Sig. (2-tailed) & 0.000 & & 0.000 & 0.741 & 0.000 & 0.000 & 0.000 & 0.000 \\
\hline \multirow[t]{2}{*}{$\mathrm{P}$} & $\begin{array}{c}\text { Pearson } \\
\text { Correlation }\end{array}$ & $0.959^{* *}$ & $0.882^{* *}$ & 1 & -0.026 & $0.936^{* *}$ & $0.527^{* *}$ & $0.368^{* *}$ & $0.619^{* *}$ \\
\hline & Sig. (2-tailed) & 0.000 & 0.000 & & 0.741 & 0.000 & 0.000 & 0.000 & 0.000 \\
\hline \multirow[t]{2}{*}{ S } & $\begin{array}{c}\text { Pearson } \\
\text { Correlation }\end{array}$ & -0.024 & -0.026 & -0.026 & 1 & $0.183^{* *}$ & -0.016 & -0.018 & -0.022 \\
\hline & Sig. (2-tailed) & 0.751 & 0.741 & 0.741 & & 0.002 & 0.865 & 0.817 & 0.767 \\
\hline \multirow[t]{2}{*}{$\mathrm{R}$} & $\begin{array}{c}\text { Pearson } \\
\text { Correlation }\end{array}$ & $0.936^{* *}$ & $0.856^{* *}$ & $0.936^{* *}$ & $0.183^{* *}$ & 1 & $0.519^{* *}$ & 0.361 ** & $0.606 * *$ \\
\hline & Sig. (2-tailed) & 0.000 & 0.000 & 0.000 & 0.002 & & 0.000 & 0.000 & 0.000 \\
\hline \multirow[t]{2}{*}{ CS } & $\begin{array}{c}\text { Pearson } \\
\text { Correlation }\end{array}$ & $0.547^{* *}$ & $0.527^{* *}$ & $0.527^{* *}$ & -0.016 & $0.519 * *$ & 1 & -0.039 & $0.424^{* *}$ \\
\hline & Sig. (2-tailed) & 0.000 & 0.000 & 0.000 & 0.865 & 0.000 & & 0.501 & 0.000 \\
\hline \multirow[t]{2}{*}{ ST } & $\begin{array}{c}\text { Pearson } \\
\text { Correlation }\end{array}$ & $0.392 * *$ & $0.368^{* *}$ & $0.368^{* *}$ & -0.018 & $0.361^{* *}$ & -0.039 & 1 & 0.672 ** \\
\hline & Sig. (2-tailed) & 0.000 & 0.000 & 0.000 & 0.817 & 0.000 & 0.501 & & 0.000 \\
\hline \multirow[t]{2}{*}{ ULT $^{a}$} & $\begin{array}{c}\text { Pearson } \\
\text { Correlation }\end{array}$ & $0.661 * *$ & $0.619^{* *}$ & $0.619^{* *}$ & -0.022 & $0.606^{* *}$ & $0.424^{* *}$ & $0.672^{* *}$ & 1 \\
\hline & Sig. (2-tailed) & 0.000 & 0.000 & 0.000 & 0.767 & 0.000 & 0.000 & 0.000 & \\
\hline
\end{tabular}

Note: CC-The Costs to Customers; MSC-Maintenance and Servicing Costs; P-Privacy; S-Security; R-Risk; CS-Customer Satisfaction; ST-Speed of Transaction; ULT-Use of Latest Technology. ${ }^{*}-p \leq 0.05,{ }^{* *}-p \leq 0.01 .{ }^{\text {a }}$ — statistical significance at the $10 \%$ level.

The results of correlation analysis suggest that respondents believe that the use of FinTech innovations can improve the competitiveness of payment systems and that technology costs in this context are of crucial importance.

\section{Discussion}

The global payments landscape is in a state of transformation. Banks and other financial institutions cannot afford to leave non-bank payment platforms and solutions out of account. Banks and other payment service providers seeking to make a profit must be aware of competitive dynamics that redefine the payments market to ensure that their propositions align with customer expectations and needs [70]. Otherwise, the appealing payment options such as PayPal, Google Wallet, Bitcoin, Facebook and M-Pesa will take over [3]. It is confirmed that in order to win the competition for payments, it is necessary to develop new forms of partnerships with modern technological financial companies [2] and adapt to the requirements of a new generation of customers. As a result of the survey, the theses of earlier works have been confirmed, testifying that players in the global payment market should become more flexible, use the latest technologies to develop cross-product offers and develop market strategies, which correspond to the needs and nature of the payment space in each market, actively focusing on fast-growing segments [6], because the modern perception of competitiveness is primarily related to safe and effective satisfaction of consumer demands.

New entrants can compete successfully in the market if they leverage their existing customer bases (e.g., Apple) or if they introduce additional services based on the existing 
infrastructure (e.g., Klarna) [26]. The competition between payment service providers is increasingly aggressive. Consumers are increasingly using more than one payment method, intensifying competition for payment methods, and the growth of digital wallet technology facilitates both front-end and back-end competition [9]. The thesis that FinTech is now becoming an integral part of the payment industry is confirmed [56], and the use of these innovations contributes to the competitiveness of payment systems [65]. Qualitative analysis undercuts the need to develop and implement innovative payment options and identify potential drivers of competitiveness in the payment market [71]. The results of this study are consistent with the view that the main factors affecting the competitiveness of the payment system are technological costs, service channels, privacy and security, quality and efficiency of service [72]. Moreover, unlike studies that have placed the main emphasis on the competitiveness of payment innovations based on user confidence in FinTech [63], in this case the results are confirmed and reveal that the greatest statistical significance is in the implementation and maintenance costs factors as well as user satisfaction $[59,68]$.

\section{Conclusions}

The present work evidences the success of approbation of an interesting economic and mathematical approach to interpreting the perception of (1) new global payment market entrants, (2) the impact of FinTech innovations on the companies' competitiveness, and (3) a quantitative assessment of the top-used quality-related competition trends. The analysis of survey results suggests that the perception of the payment system's competitiveness is largely associated with low technology costs and efficient customer satisfaction. At the same time, factors such as high quality and efficiency of the payment product or service, high speed of transactions, security, privacy, and low risk are also perceived as important. In general, the use of FinTech innovations is expected to improve the competitiveness of payment systems $(\mathrm{M}=4.32)$.

From the analysis of the ordered logistic regression results, the examined factors collectively explain almost half of the variation in perceptions (Pseudo R-Squared $=0.4886$ ). Variables that yield statistically significant coefficients are 'implementation costs' $(\mathrm{z}=1.74)$, 'maintenance and servicing costs' $(z=3.30)$, and 'customer satisfaction' $(z=3.15)$. The analysis of correlations indicates that the perception of FinTech innovations is that they determine the competitiveness of payment systems.

The study has some limitations, which include decisions made about the research procedure-they make it difficult to use the criterion of agreement to assess differences in the distribution across geographic groups. The lack of opportunity to form a research sample based on FinTech companies' distribution by country should be perceived as a source of possible uncertainty. In the future, it would be interesting to study the perception of global payment system competitiveness factors, taking into account the regional aspect of financial companies' operations.

Nevertheless, the study managed to analyze the perception of FinTech innovation implementation by new market participants and offer a simple economic-mathematical approach to the interpretation of factors affecting the global competition of payment systems. The approach is recommended when developing a competitive market strategy for FinTech companies wishing to achieve a high competitive position.

The findings obtained may be of interest to specialists and researchers dealing with the dynamics of competition in the global payment business, payment innovations, or the convergence and transformation of the payment industry. The proposed approach is also expected to contribute to the development of interdisciplinarity and expand the range of contact points of the journal's readership from related fields. 
Author Contributions: Conceptualization, M.M., A.K. and B.Ś.; methodology, D.S.; software, D.S.; validation, X.C., M.M., D.S., A.K. and B.Ś.; formal analysis, X.C. and D.S.; investigation, M.M.; resources, A.K. and A.K.; data curation, D.S. and B.S.; writing-original draft preparation, X.C.; writing-review and editing, M.M. and B.Ś.; visualization, A.K.; supervision, X.C. and B.Ś.; project administration, M.M.; funding acquisition, X.C. All authors have read and agreed to the published version of the manuscript.

Funding: Xinyu Cai was funded by Capital University of Economics and Business, Postgraduate Academic Newcomer Program Project, grant number 2021XSXR14.

Institutional Review Board Statement: Not applicable.

Informed Consent Statement: Not applicable.

Data Availability Statement: Data will be available on request.

Acknowledgments: Xinyu Cai was funded by Capital University of Economics and Business, Postgraduate Academic Newcomer Program Project, grant number 2021XSXR14.

Conflicts of Interest: The authors declare no conflict of interest.

\section{References}

1. Gardner, G.; Stone, A. Competition between payment systems. In RBA Research Discussion Papers; Reserve Bank of Australia: Sydney, Australia, 2009.

2. Menezes, A.D.; Pinto, P. Evolution of payment system. Int. J. Manag. Technol. Soc. Sci. 2017, 2, 45-52. [CrossRef]

3. Ehrentraud, J.; Ocampo, D.G.; Garzoni, L.; Piccolo, M. Policy responses to FinTech: A cross-country overview. Financial Stability Institute. FSI Insights 2020, 23.

4. Bott, J.; Milkau, U. A market for payments-Payment choice in the 21st century digital economy. In Transforming Payment Systems in Europe; Palgrave Macmillan: London, UK, 2016; pp. 1-27.

5. Berg, D.; Demina, M.; Isaichik, K.; Panachev, A.; Popkov, V.; Parusheva, S. Competition of payment systems in Russia: Numerical analysis. AIP Conf. Proc. 2018, 2040, 050014.

6. Goldbarsht, D. New payment systems. In Assets, Crimes, and the State; Routledge: London, UK, 2020; pp. 125-139.

7. Kormych, B.; Averochkina, T.; Gaverskyi, V. The public administration of territorial seas: Ukrainian case. Int. Environ. Agreem. Politics Law Econ. 2020, 20, 577-595. [CrossRef]

8. Sarina, S.A.; Nukusheva, A.A.; Kalmagambetov, K.S.; Kumysbekova, Z.T.; Nesterova, E.V. Confession and carrying into execution of foreign arbitration courts' decisions: Reciprocity and public policy. Int. J. Environ. Sci. Educ. 2016, 11, 4760-4767.

9. Liébana-Cabanillas, F.; García-Maroto, I.; Muñoz-Leiva, F.; Ramos-de-Luna, I. Mobile payment adoption in the age of digital transformation: The case of apple pay. Sustainability 2020, 12, 5443. [CrossRef]

10. Hosny, A. Remittance concentration and volatility: Evidence from 72 developing countries. Int. Econ. J. 2020, $2020.34,553-570$. [CrossRef]

11. Sanusi, K.A.; Meyer, D.; Ślusarczyk, B. The relationship between changes in inflation and financial development. Pol. J. Manag. Stud. 2017, 16, 253-265. [CrossRef]

12. World Bank. World Bank Predicts Sharpest Decline of Remittances in Recent History. 2020. Available online: https://www. worldbank.org/en/news/press-release/2020/04/22/world-bank-predicts-sharpest-decline-of-remittances-in-recent-history (accessed on 15 April 2021).

13. Bartes, F.; Studeníková, J. Payment system competitiveness. Equilibrium 2010, 5, 93-101. [CrossRef]

14. Ugolini, S. The payment system. In The Evolution of Central Banking: Theory and History; Palgrave Macmillan: London, UK, 2017; pp. 21-100.

15. Crowe, M.; McGuire, B. 2019 Results from the Mobile Banking and Payments Survey of New England Financial Institutions; Federal Reserve Bank of Boston: Boston, MA, USA, 2020.

16. Liu, J.; Kauffman, R.J.; Ma, D. Competition, cooperation, and regulation: Understanding the evolution of the mobile payments technology ecosystem. Electron. Commer. Res. Appl. 2015, 14, 372-391. [CrossRef]

17. Kasasbeh, E.A.; Harada, Y.; Noor, I.M. Factors influencing competitive advantage in banking sector: A systematic literature review. Res. J. Bus. Manag. 2017, 11, 67-73. [CrossRef]

18. Champ, B.; Freeman, S.; Haslag, J. The payments system. In Modeling Monetary Economies; Cambridge University Press: Cambridge, UK, 2016; pp. 229-251.

19. Malyarets, L.; Dorokhov, O.; Koybichuk, V.; Dorokhova, L. Obtaining a generalized index of bank competitiveness using a fuzzy approach. J. Cental Bank. Theory Pract. 2019, 8, 163-182. [CrossRef]

20. Boone, J.; van Ours, J.C.; van der Wiel, H. When is the price cost margin a safe way to measure changes in competition? De Econ. 2013, 161, 45-67. [CrossRef]

21. Berger, A.N.; Klapper, L.F.; Turk-Ariss, R. Bank competition and financial stability. J. Financ. Serv. Res. 2009, 35, 99-118. [CrossRef] 
22. Carbó, S.; Humphrey, D.; Maudos, J.; Molyneux, P. Cross-country comparisons of competition and pricing power in European banking. J. Int. Money Financ. 2009, 28, 115-134. [CrossRef]

23. Liu, H.; Molyneux, P.; Wilson, J.O. Competition in banking: Measurement and interpretation. In Handbook of Research Methods and Applications in Empirical Finance; Edward Elgar Publishing: Cheltenham, UK, 2013; pp. 197-215.

24. Chen, W.K.; Nalluri, V.; Lin, M.L.; Lin, C.T. Identifying decisive socio-political sustainability barriers in the supply chain of banking sector in India: Causality analysis using ISM and MICMAC. Mathematics 2021, 9, 240. [CrossRef]

25. Bourreau, M.; Valetti, T. Competition and interoperability in mobile money platform markets: What works and what doesn't? Commun. Strateg. 2015, 99, 11.

26. Worldpay. 2020 Global Payments Report: Five eCommerce Takeaways. 2020. Available online: https://worldpay. globalpaymentsreport.com/\#/en/insights (accessed on 15 April 2021).

27. Oxera. The Competitive Landscape for Payments: A European Perspective. 2020. Available online: https://www.oxera.com/wpcontent/uploads/2020/03/Competitive-landscape-report.pdf (accessed on 15 April 2021).

28. Accenture. Payments Models for the Digital Age 2020. 2020. Available online: https://www.accenture.com/_acnmedia/PDF-81 / Accenture-Payments-in-the-Digital-Age.pdf (accessed on 15 April 2021).

29. Jeziorski, P. Mobile payment systems. In The Routledge Companion to Strategic Marketing; Routledge: London, UK, 2020 ; pp. 325-338.

30. The Bank of New York Mellon Corporation. Global Payments 2020: Transformation and Convergence. 2014. Available online: https:/ / www.bnymellon.com/content/dam/bnymellon/documents/pdf/articles/global-payments-2020-transformationand-convergence.pdf (accessed on 15 April 2021).

31. Carstens, A. Shaping the future of payments. BIS Q. Rev. 2020, 1, 17-20.

32. Erlandsson, F.; Guibourg, G. Economic Commentaries: Times Are Changing and so Are Payment Patterns; Sveriges Riksbank: Stockholm, Sweden, 2018.

33. Koghut, M.; AI-Tabbaa, O. Exploring consumers' discontinuance intention of remote mobile payments during post-adoption usage: An empirical study. Adm. Sci. 2021, 11, 18. [CrossRef]

34. The International Bank for Reconstruction and Development/The World Bank Group. Payment Systems Worldwide a Snapshot. Summary Outcomes of the Fifth Global Payment Systems Survey. 2020. Available online: http:/ /documents1.worldbank.org/ curated/en/115211594375402373/pdf/A-Snapshot.pdf (accessed on 15 April 2021).

35. Romānova, I.; Kudinska, M. Banking and FinTech: A challenge or opportunity? In Contemporary Issues in Finance: Current Challenges from Across Europe; Emerald Group Publishing Limited: Bingley, UK, 2016; pp. 21-35.

36. Arnold, M.; Wildau, G. China UnionPay Kicks off European Expansion with UK Launch. Financial Times. 2018. Available online: https://www.ft.com/content/61bceaf2-b98d-11e8-8274-55b72926558f (accessed on 15 April 2021).

37. Jocevski, M.; Ghezzi, A.; Arvidsson, N. Exploring the growth challenge of mobile payment platforms: A business model perspective. Electron. Commer. Res. Appl. 2020, 40, 100908. [CrossRef]

38. Fonina, T.B.; Mishchenko, I.V.; Latysheva, V.V.; Romanova, I.N. The approach to managing the development of industry 4.0 in the conditions of knowledge economy's formation for implementation of the optimal scenario. In Industry 4.0: Industrial Revolution of the 21st Century; Springer: Cham, Switzerland, 2019; pp. 245-251.

39. McKinsey and Company. Global Payments Report 2019: Amid Sustained Growth, Accelerating Challenges Demand Bold Actions. 2019. Available online: https:/ / www.mckinsey.com/ \{\}/media/mckinsey/industries/financial\%20services/our\%20insights / tracking\%20the\%20sources\%20of\%20robust\%20payments\%20growth\%20mckinsey\%20global\%20payments\%20map/globalpayments-report-2019-amid-sustained-growth-vf.ashx (accessed on 15 April 2021).

40. Arvidsson, N. The payment landscape in Sweden. In The Rise and Development of Fintech; Routledge: London, UK, 2018; pp. 238-252.

41. Hassan, M.A.; Shukur, Z.; Hasan, M.K.; Al-Khaleefa, A.S. A review on electronic payments security. Symmetry 2020, $12,1344$. [CrossRef]

42. Dospinescu, O. Mobile payments. From mobility to security. Rev. Tinerilor Econ. 2012, 19, 190-193.

43. He, M.D.; Leckow, R.B.; Haksar, V.; Griffoli, T.M.; Jenkinson, N.; Kashima, M.; Khiaonarong, T.; Rochon, C.; Tourpe, H. Fintech and Financial Services: Initial Considerations; International Monetary Fund: Washington, DC, WA, USA, 2017.

44. Mills, K.G. Fintech, Small Business \& the American Dream: How Technology Is Transforming Lending and Shaping a New Era of Small Business Opportunity; Springer: Cham, Switzerland, 2019.

45. Mignot, V. Paiement Par Carte Bancaire: Vers la fin de l'exception Française? Cbanque. 2016. Available online: https://www. moneyvox.fr/carte-bancaire/actualites/58646/paiement-par-carte-bancaire-vers-la-fin-de-exception-francaise (accessed on 15 April 2021).

46. Yeh, H. Factors in the ecosystem of mobile payment affecting its use: From the customers' perspective in Taiwan. J. Theor. Appl. Electron. Commer. Res. 2020, 15, 13-29. [CrossRef]

47. Leatherby, L.; Gelles, D. How the Virus Transformed the Way Americans Spend Their Money. New York Times. 2020. Available online: https://www.nytimes.com/interactive/2020/04/11/business/economy/coronavirus-us-economy-spending.html (accessed on 15 April 2021).

48. Auer, R.; Cornelli, G.; Frost, J. Covid-19, Cash and the Future of Payments; Bank for International Settlements: Basel, Switzerland, 2020. 
49. Hammoud, J.; Bizri, R.M.; El Baba, I. The impact of e-banking service quality on customer satisfaction: Evidence from the lebanese banking sector. SAGE Open 2018, 8, 1-12. [CrossRef]

50. Europe1. Apple Pay: Les Banques Françaises Mettent de Côté Leurs Réticences. 2018. Available online: https://www.europe1.fr/ technologies / apple-pay-les-banques-francaises-mettent-de-cote-leurs-reticences-3736847 (accessed on 15 April 2021).

51. Hernaes, C. What Facebook's European payment license could mean for banks. TechCrunch. 2016. Available online: https: //techcrunch.com/2017/01/12/what-facebooks-european-payment-license-could-mean-for-banks/ (accessed on 15 April 2021).

52. Taylor, C. Google Gets Go-Ahead from Central Bank for Payments. The Irish Times. 2019. Available online: https://www.irishtimes. com/business/technology/google-gets-go-ahead-from-central-bank-for-payments-1.3747901 (accessed on 15 April 2021).

53. Mastercard. Mastercard and Paypal Expand Digital Partnership Globally. 2017. Available online: https://newsroom.mastercard. $\mathrm{com} /$ press-releases/mastercard-and-paypal-expand-digital-partnership-globally/ (accessed on 15 April 2021).

54. E-commerce News Europe. Top 3 of Payment Methods per European Country. 2018. Available online: https:/ / ecommercenews. eu/top-3-payment-methods-per-european-country/ (accessed on 15 April 2021).

55. Nicoletti, B. Proposition of value and Fintech organizations in Banking 5.0. In Banking 5.0. Palgrave Studies in Financial Services Technology; Palgrave Macmillan: Cham, Switzerland, 2021; pp. 91-152.

56. Romānova, I.; Grima, S.; Spiteri, J.; Kudinska, M. The payment services directive ii and competitiveness: The perspective of European FinTech companies. Eur. Res. Stud. J. 2018, 21, 5-24. [CrossRef]

57. Arner, D.W.; Barberis, J.; Buckley, R.P. The Evolution of FinTech: A New Post-Crisis Paradigm? University of Hong Kong Faculty of Law: Hong Kong, China, 2015.

58. Wildau, G.; Jia, Y. China Moves to Impose Order on Mobile Payments Boom. Financial Times. 2017. Available online: https: //www.ft.com/content/b7866e7c-eb8e-11e7-bd17-521324c81e23 (accessed on 15 April 2021).

59. Meola, A. The Future of Banking: Growth of Innovative Banking FinTech Services. Business Insider, 2016. Available online: http:/ / www.businessinsider.com/the-future-of-banking-growth-of-innovative-banking-fintech-services-2016-12 (accessed on 15 April 2021).

60. Hochstein, M. FinTech (the Word, That is) Evolves. The American Banker. 2015. Available online: https://www.americanbanker. com/opinion/fintech-the-word-that-is-evolves (accessed on 15 April 2021).

61. Liu, Z.; Shestak, V. Issues of crowdsourcing and mobile app development through the intellectual property protection of third parties. Peer Peer Netw. Appl. 2021, 14, 2618-2625. [CrossRef]

62. Dospinescu, O.; Dospinescu, N.; Agheorghiesei, D.-T. FinTech services and factors determining the expected benefits of users: Evidence in Romania for Millennials and Generation Z. E + M Ekon. Manag. 2021, 24, 101-118. [CrossRef]

63. Hu, Z.; Ding, S.; Li, S.; Chen, L.; Yang, S. Adoption intention of fintech services for bank users: An empirical examination with an extended technology acceptance model. Symmetry 2019, 11, 340. [CrossRef]

64. Mirzaei, A.; Moore, T. What are the driving forces of bank competition across different income groups of countries? J. Int. Financ. Mark. 2014, 32, 38-71. [CrossRef]

65. Dubey, V. FinTech innovations in digital banking. Int. J. Eng. Technol. 2019, 8, 597-601.

66. Jegher, J.; Lodge, G.; Zhang, H. IT Spending in Banking, a Global Perspective. Celent, 2015. Available online: http:/ / celent.com/ reports/it-spending-banking-global-perspective-2 (accessed on 15 April 2021).

67. Krueger, M. Costs and Benefits of Cash and Cashless Payment Instruments in Germany. Module 1, Overview and Initial Estimates, Expertise for the Deutsche Bundesbank; Deutsche Bundesbank: Frankfurt, Germany, 2014.

68. Alt, R.; Beck, R.; Smits, M.T. FinTech and the transformation of the financial industry. Electron. Mark. 2018, 28, 235-243. [CrossRef]

69. Emerson, R.W. Likert scales. J. Vis. Impair. Blind. 2017, 111, 488. [CrossRef]

70. Dyson, B.; Hodgson, G. How to Increase Competition and Innovation in Payment Services by Widening Access to Accounts at the Bank of England. Positive Money, 2014. Available online: https://positivemoney.org/wp-content/uploads/2014/12/ Competition-in-Payment-Services.pdf (accessed on 15 April 2021).

71. Glushchenko, M.; Hodasevich, N.; Kaufman, N. Innovative financial technologies as a factor of competitiveness in the banking. SHS Web Conf. 2019, 69, 00043. [CrossRef]

72. Carmona, A.F.; Lombardo, A.G.Q.; Pastor, R.R.; Quirós, C.T.; García, J.V.; Muñoz, D.R.; Martin, L.C. Competition Issues in the area of Financial Technology (fintech). Directorate General for Internal Policies. Policy Department A: Economic and Scientific Policy. 2018. Available online: https:/ / www.europarl.europa.eu/RegData/etudes/STUD/2018/619027/IPOL_STU(2018)619 027_EN.pdf (accessed on 15 April 2021). 